\title{
QUIS INTERAKTIF MATEMATIKA UNTUK ANAK SEKOLAH DASAR
}

\author{
Asnawati ${ }^{1}$, Venny Novita Sari $^{2}$, Cristine Natalia ${ }^{3}$ \\ 1,2,3Program Studi Sistem Informasi Fakultas Ilmu Komputer Universitas Dehasen Bengkulu \\ Jalan Meranti Raya No.32 Kelurahan Sawah Lebar Kota Bengkulu Telp. (0736) 22027, 26957 Fax. (0736) 341139 \\ asna_pkg@yahoo.co.id
}

\begin{abstract}
The purpose of this research is to create interactive quiz math for elementary school children. Which is expected to increase the interest of children's learning and can be used as a learning tool and a children's playground. Data collection method used is the method of observation, interviews, and literature. The method used in this research is the method of literature study and field study by observing the actual system, the new system and analyze the old data. As well as using the method of system development by preparing a new system to replace the old system as a whole or improve existing systems. Based on the results and discussion as well as the results of testing the system, it can be concluded bahwaquis interactive math for elementary school children Negeri 09 Curup South were developed with the help of program Adobe Flash CS 5.5, suitable for play facilities and children's learning as well as the introduction of computers to children Elementary School 09 Curup South.Program these applications can be run / used on computers with different specifications. As a new alternative for tutors, teachers or parents to teach children math while playing to further enhance the knowledge of children about math material.
\end{abstract}

Keywords: Quiz Mathematics, Adobe Flash CS 5.5

INTISARI

Tujuan dari penelitian ini adalah membuat quis interaktif matematika untuk anak sekolah dasar. Yang diharapkan menambah minat belajar anak-anak dan dapat digunakan sebagai alat bantu belajar dan bermain anak. Metode pengumpulan data yang digunakan yaitu metode observasi, wawancara dan studi pustaka. Metode penelitian yang digunakan dalam penelitian ini adalah metode studi pustaka dan studi lapangan dengan memperhatikan sistem aktual, sistem yang baru dan menganalisa data yang lama. Serta menggunakan metode pengembangan sistem dengan menyusun sistem yang baru untuk menggantikan sistem yang lama secara keseluruhan atau memperbaiki sistem yang ada. Berdasarkan hasil dan pembahasan serta hasil pengujian sistem, dapat disimpulkan bahwa quis interaktif matematika untuk anak Sekolah Dasar Negeri 09 Curup Selatan yang dikembangkan dengan bantuan program Adobe Flash CS 5.5, sesuai digunakan untuk sarana bermain dan belajar anak serta pengenalan komputer terhadap anak SD Negeri 09 Curup Selatan.Program aplikasi ini dapat dijalankan/digunakan pada komputer dengan spesifikasi yang berbeda.Sebagai alternatif baru bagi tutor, guru atau orang tua mengajarkan anak matematika sambil bermain untuk lebih meningkatkan pengetahuan anak tentang materi matematika.

Kata Kunci : Quis Matematika, Adobe Flash CS 5.5

\section{PENDAHULUAN}

Seiring dengan pesatnya kemajuan teknologi saat ini, komputer tidak hanya digunakan oleh kalangan tertentu, berbagai macam orang dengan berbagai latar belakang pendidikan dan usia menggunakan komputer. Teknologi informasi pun telah diterapkan dalam berbagai metode edukasi oleh orang tua guna mencerdaskan anak.

Edukasi atau bisa disebut dengan pendidikan, merupakan proses dari pembelajaran pengetahuan, keterampilan dan kebiasaan sekelompok orang yang diturunkan dari satu generasi ke generasi berikutnya melalui pengajaran, pelatihan, atau penelitian. Edukasi biasanya terjadi di bawah bimbingan orang lain, tetapi dizaman yang modern ini sudah banyak yang mendapatkan edukasi secara otodidak.
Dalam berbagai pelajaran yang ada disekolah, beberapa mata pelajaran disekolah dapat ditanamkan melalui permainan-permainan, sehingga dapat lebih menanamkan nilai-nilai edukasi melalui permainan. Melihat sifat anak-anak yang masih gemar bermain dan berimajinasi, maka media interaktif berbasis multimedia menjadi pilihanbaik untuk mengemasnya. Dengan perpaduan teks, suara dan gambar yang disukai anak-anak terutama sekolah dasar, sehingga menimbulkan rasa ingin tahu anak dalam materi terutama materi matematika.

Sebagai upaya dalam menindaklanjuti masalah diatas sekiranya diperlukanmetode untuk meningkatkan rasa ingin tahu anak, dengan memanfaatkan perkembangan teknologi, salah satunya penggunaan quis interaktif. Karena pengguna komputer dapat menambah efesiensi kegiatan belajar 
mengajar dan mengevaluasi diri dengan soal-soal interaktif sehingga dapat merangsang kecerdasan otak.

Berdasarkan dari uraian latar belakang diatas,maka permasalahan yang akan dibahas adalah "Bagaimana cara membuat Quis Interaktif Matematika Untuk Anak Sekolah Dasar?”.

\section{TINJAUAN PUSTAKA}

\section{A) Multimedia}

Menurut Vaughan (2011:01), multimedia merupakan kombinasi teks, seni, suara, gambar, animasi dan vidio yang disampaikan dengan komputer atau dimanipulasi secara digital dan dapat disampaikan dan dikontrol secara interaktif. Dalam ilmu komunikasi, media bisa diartikan sebagai saluran, sarana penghubung dan alat-alat komunikasi. Menurut Vaughan (2011:13) ada tiga jenis multimedia, yaitu :

\section{1) Multimedia interaktif}

Pengguna dapat mengontrol apa dan kapan elemen-elemen multimedia akan dikirim atau ditampilkan.

\section{2) Multimedia Hiperaktif}

Multimedia jenis ini mempunyai suatu struktur dari elemen-elemen terkait dengan pengguna yang dapat mengarahkannya.

\section{3) Multimedia linear}

Pengguna hanya menjadi penonton dan menikmati produk multimedia yang disajikan dari awal hingga akhir.

Multimedia memiliki elemen-elemen yang meliputi teks, gambar, suara. Di dalam aplikasi, keseluruhan elemen tersebut disatukan hingga membentuk satu kesatuan aplikasi yang harmonis. Pada penelitian dalam pembuatan quis interaktif matematika untuk anak sekolah dasar menggunakan jenis multimedia interaktif.

\section{B) Quis Ineraktif}

\section{1) Quis}

Purnama (2008:1) bagi kalangan pendidik, pemberian tugas quis mempunyai arti dan tujuan sendiri bagi murid-muridnya. Quis sering kali dijadikan instrumen untuk mengukur tingkat pencapaian siswa dalam menguasai suatu materi pelajaran. Dengan kata lain, guru memberikan quis sebagai bagian dari assessment terhadap siswanya.

Jadi, pemberian quis digunakan untuk mengukur kesiapan dari siswa untuk mengikuti pembelajaran yang akan ditrerima. Kuis merangsang siswa untuk belajar dan juga merupakan pembelajaran dua arah.

\section{2) Interaktif}

Kamus Besar Bahasa Indonesia (2008:542), interaktif merupakan kegiatan saling melakukan aksi, antar hubungan, saling aktif. Komunikasi lebih dari satu, atau bersifat banyak juga bisa disebut interaktif. Salah satunya quis interaktif dapat dikatakan interaktif apabila siswa tidak hanya melihat dan mendengar tetapi secara nyata berinteraksi langsung dengan pengajar, seperti menjawab pertanyaan yang diajukan guru, memberikan pendapat pada proses pembelajaran, dan juga saling berdiskusi dengan teman. Semua itu merupakan suatu proses interaktif di dalam kelas.

\section{3) Matematika}

Menurut Farida (2009:3) Matematika adalah ilmu yang mempelajari tentang logika berfikir dan bernalar. Oleh karena itu matematika digunakan sebagai alat bantu untuk mengatasi masalah-masalah pada bidang lainnya, sehingga matematika mempunyai peranan penting dalam kehidupan seharihari. Dengan belajar mtematika, maka siswa diharapkan mampu berpikir logis dan sistematis, serta dapat mengatasi masalahnya sehari-hari.

Matematika pada kenyataannya sangat bermanfaat bagi kehidupan, perkembangan sains dan teknologi, sampai upaya melestarikan alam, matematika hidup di alam gagasan, bukan di realita atau kenyataan. Uniknya, kebebasannya dari kenyataan dan pengaruh manusia ini nantinya justru memungkinkan penyimpulan pernyataan bahwa semesta ini merupakan sebuah struktur matematika.

Melalui penggunaan penalaran logika dan abstraksi, matematika berkembang dari pencacahan, perhitungan, pengukuran, dan pengkajian sistematis terhadap bangun dan pergerakan benda-benda fisika. Matematika praktis dalam kegiatan manusia sejak adanya rekaman tertulis.

Kini, matematika digunakan di seluruh dunia sebagai alat penting di berbagai bidang, termasuk ilmu alam, teknik, kedokteran/medis, dan ilmu sosial seperti ekonomi, dan psikologi. Matematika terapan, cabang matematika yang melingkupi penerapan pengetahuan matematika ke bidang-bidang lain, mengilhami dan membuat penggunaan temuantemuan matematika baru, dan kadang-kadang mengarah pada pengembangan disiplin-disiplin ilmu yang sepenuhnya baru, seperti statistika dan teori permainan.

Para matematikawan juga bergulat di dalam matematika murni, atau matematika untuk perkembangan matematika itu sendiri. Mereka berupaya menjawab pertanyaan-pertanyaan yang muncul di dalam pikirannya, walaupun belum diketahui penerapannya.

\section{4) Sekolah Dasar}

Sekolah Dasar (SD) umumnya memiliki siswa yang umurnya berkisar 6 atau 7 tahun, sampai 12 atau 13 tahun. Sekolah dasar merupakan jenjang paling dasar pada pendidikan formal di Indonesia. Sekolah dasar ditempuh dalam waktu 6 tahun, mulai dari kelas 
1 sampai dengan kelas 6. Sekolah dasar diselenggarakan oleh pemerintah maupun swasta. Sejak diberlakukannya otonomi daerah pada tahun 2001, pengelolaan sekolah dasar negeri di Indonesia yang sebelumnya berada dibawah Departemen Pendidikan Nasional, kini menjadi tanggung jawab pemerintah daerah kabupaten/kota. sedangkan departemen Pendidikan Nasional hanya berperan sebagai regulator dalam bidang standar nasional pendidikan. Secara struktural, sekolah dasar negeri merupakan unit pelaksanaan teknis dinas pendidikan kabupaten/kota (wikipedia.org, 2016).

\section{METODOLOGI PENELITIAN}

\section{A) Metode Penelitian}

Metode yang digunakan dalam penelitian ini adalah metode studi pustaka dan studi lapangan dengan memperhatikan sistem aktual, sistem yang baru dan menganalisa data yang lama. Serta menggunakan metode pengembangan sistem dengan menyusun sistem yang baru untuk menggantikan sistem yang lama secara keseluruhan atau memperbaiki sistem yang ada.

\section{B) Metode Pengumpulan Data}

Metode pengumpulan data yang digunakan dalam penelitian ini adalah:

\section{1) Observasi}

Memperoleh data dengan melakukan pengamatan secara langsung terhadap objek yang di teliti yaitu pada sistem pelaksanaan quis interaktif matematika untuk anak sekolah dasar.

\section{2) Wawancara}

Penulis melakukan wawancara untuk mendapatkan informasi dan data-data yang relevan kepada guru matematika.

3) Studi Pustaka

Mengumpulkan data dari buku-buku yang ada hubungannya dengan permasalahan yang dibahas.

\section{C) Perancangan Sistem}

\section{1) Analisa Sistem Aktual}

Pada SD Negeri 09 Curup Selatan dalam memberikan kuis, siswa belajar menggunakan alat bantu buku dan papan tulis dengan metode pembelajaran yang masih sederhana, seperti penyampaian materi oleh guru, menirukan bacaan, dan lain-lain. Seiring dengan perkembangan teknologi yang begitu pesat maka perlu adanya penyesuaian dengan teknologi dan media interaktif yang berkembang pada saat ini.

\section{2) Analisa Sistem Baru}

Pada perancangan sistem baru, peneliti akan merancang sebuah program media quis interaktif yang menggunakan visual, audio, dan animasi.Animasi yang dibuat dalam bentuk 2D (dimensi). Quis interaktif dirancang sesuai dengan materi dan tingkatan yang ada pada masing-masing kelas di SD Negeri 09 Curup Selatan. Quis interaktif juga dirancang tanpa batas waktu pengisian jawaban, sehingga dapat lebih leluasa dalam pengisian jawaban soal-soal interaktif.

\section{3) Struktur Menu}

Adapun struktur menu yang penulis rancang pada Interaktif quis ini dapat dilihat pada Gambar 1.

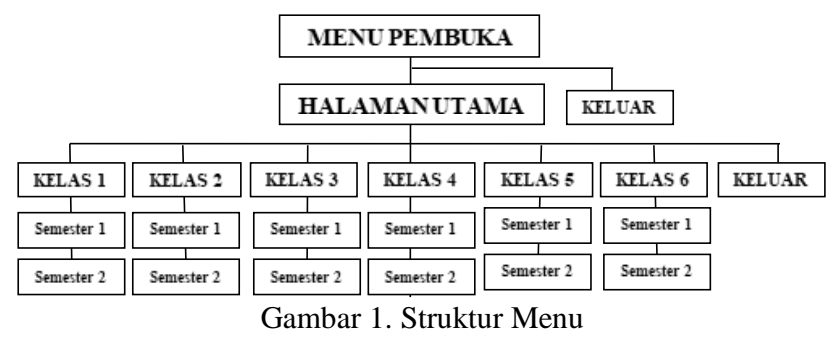

\section{D) Perancangan Pengujian}

Pengujian sistem dalam hal ini adalah pembuatan program media pembelajaran interaktif untuk siswa kelas 1 sampai dengan kelas 6SD Negeri 09 Curup Selatan. Pengujian merupakan bagian yang penting dalam siklus pembangunan quis interaktif. Pengujian dilakukan untuk menjamin kualitas dan juga mengetahui kelemahan dari program.

Dalam pengujian program digunakan suatu metode pengujian yang berfokus pada aplikasi program quis interaktif 2D untuk anak sekolah dasar ditampilkan dengan melakukan sosialisasi program pada anak-anak sekolah dasar dan guru serta orang tua siswa, dan melakukan penyebaran kuisioner.

\section{PEMBAhasan}

\section{A) Hasil dan Pembahasan}

Adapun hasil penelitian ini adalah tercipta program aplikasi quis interaktif matematika untuk anak sekolah dasar yang di dalamnya terdapat quis yang menggunakan animasi gambar, teks dan suara.

Pembuatan aplikasi quis interaktif matematika untuk anak sekolah dasar ini menggunakan Adobe Flash CS 5.5 dengan Action Script 2.0 yang disimpan dengan file ekstensi (.exe) untuk dapat langsung dijalankan dikomputer tanpa penginstalan software Adobe Flash CS 5.5. File flash (.fla) sebesar 125.531 Kilo Byte, sedangkan ukuran file flash (.swf) sebesar 8.282 Kilo Byte, dan file flash (.exe) sebesar 13.791 
Kilo Byte. File yang diberikan kepada pengguna tidak dapat diubah.

\section{1) Мenu Pembuka}

Menu pembuka merupakan tampilan awal dari aplikasi program quis interaktif matematika untuk anak sekolah dasar yang terdapat nama sekolah dan logo dinas pendidikan juga terdapat judul dari aplikasi. Terdapat juga tombol masuk untuk menuju ke halaman utama, terdapat tombol about us yang menuju ke halaman about us dan tombol keluar untuk keluar atau batal bermain. Untuk lebih jelas tampilan dilihat dari Gambar 2.

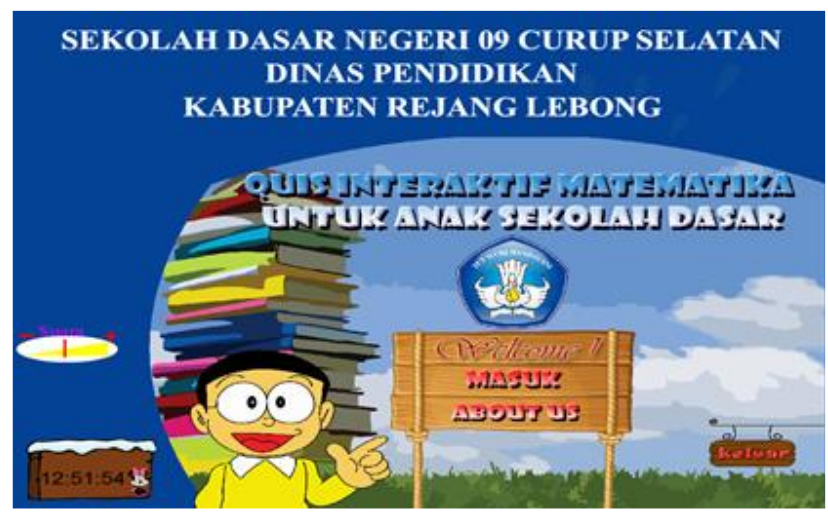

Gambar 2. Tampilan Menu Pembuka

\section{2) Мепи Utama}

Menu utama merupakan tampilan kedua setelah menu pembuka. Tampilan menu utama terdiri dari tombol kelas 1, kelas 2, kelas 3, kelas 4, kelas 5, dan kelas 6. Dan juga terdapat tombol keluar yang menuju kembali ke halaman tampilan menu pembuka. Pada tampilan menu utama terdapat pula animasi logo, dan jam yang menujukan waktu terkini serta tombol pengeras dan pengecil suara yang berfungsi mengecilkan dan membesarkan latar suara dari aplikasi. Bentuk dari tampilan menu utama ini dapat dilihat pada Gambar 3.

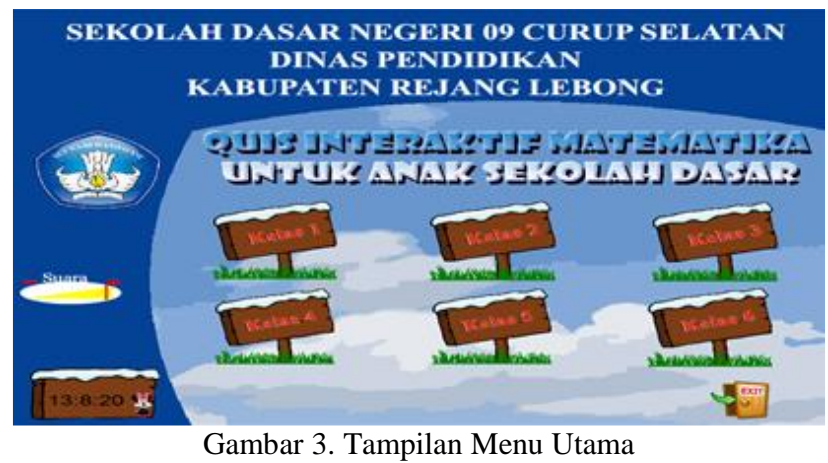

\section{3) Menu Kelas 1}

Pada pilihan tombol kelas 1 terdapat sub menu tampilan pilihan semester dan tampilan soal per semester.

\section{a) Sub Menu Semester Kelas 1}

Pada tampilan sub menu semester kelas 1 terdapat 2 pilihan semester.

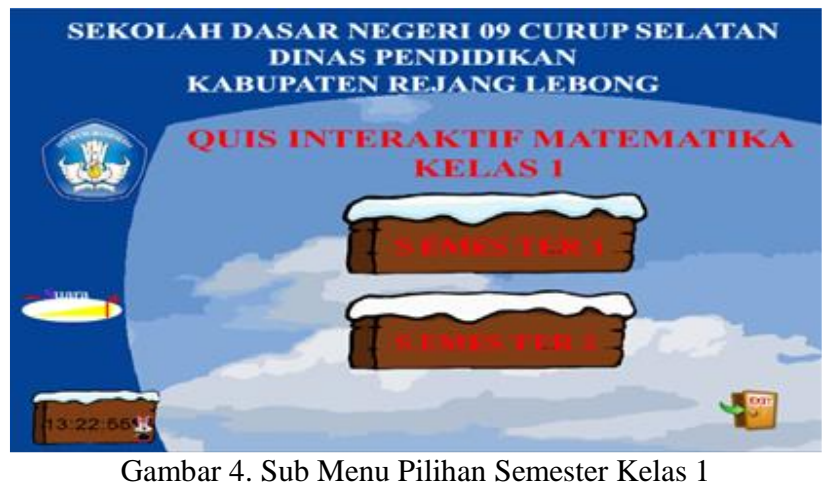

b) Sub Menu Soal Kelas 1 Semester 1

Pada sub menu ini terdapat 5 soal matematika kelas 1 semester 1 .

\section{Soal 1}

Berikut tampilan soal pertama dari pilihan sub menu soal kelas 1 semester 1 .

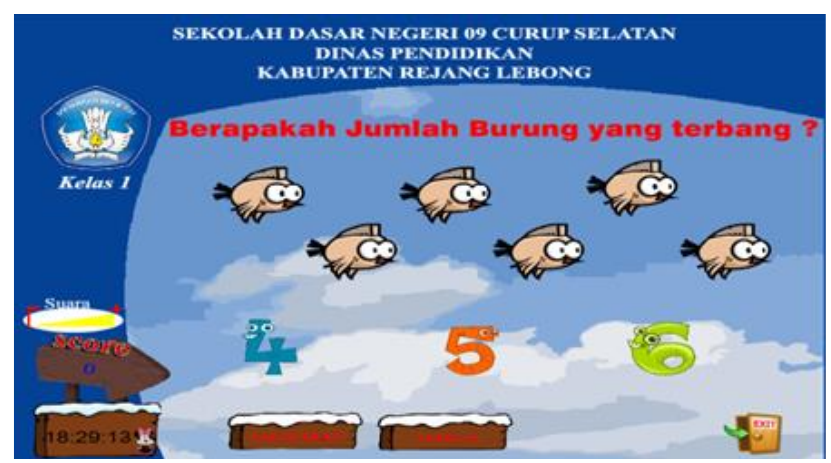

Gambar 5. Tampilan Soal 1Untuk Kelas 1 Semester 1

Soal 2

Berikut tampilan soal kedua dari pilihan sub menu soal kelas 1 semester 1 .

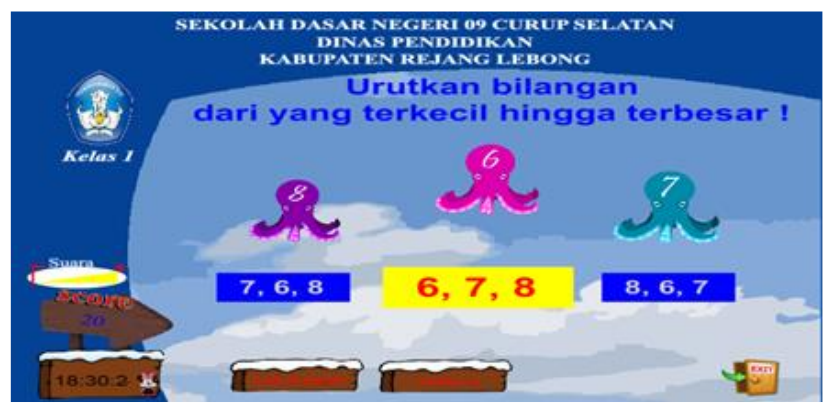

Gambar 6. Tampilan Soal 2 Untuk Kelas 1 Semester 1

\section{Soal 3}

Berikut tampilan soal ketiga dari pilihan sub menu soal kelas 1 semester 1 . 


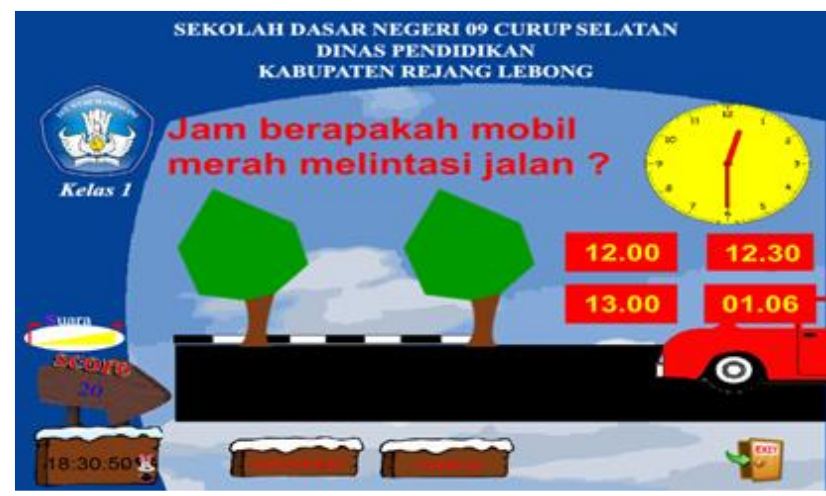

Gambar 7. Tampilan Soal 3 Untuk Kelas 1 Semester 1

\section{Soal 4}

Berikut tampilan soal keempat dari pilihan sub menu soal kelas 1 semester 1 .

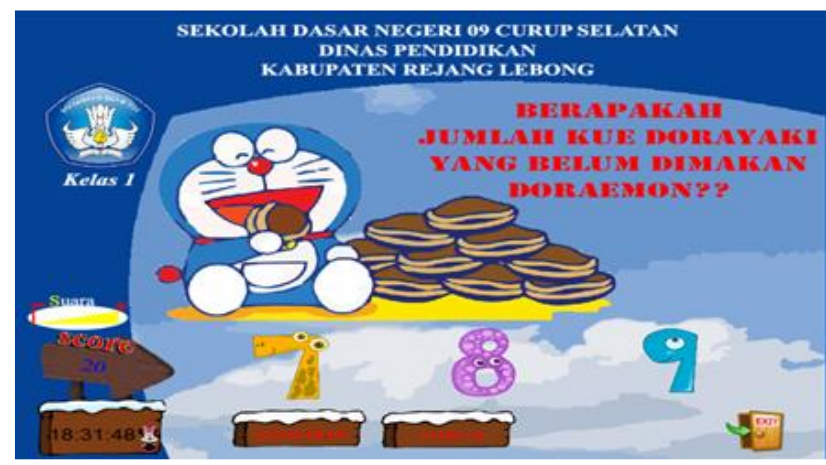

Gambar 8. Tampilan Soal 4 Untuk Kelas 1 Semester 1

Soal 5

Berikut tampilan soal kelima dari pilihan sub menu soal kelas 1 semester 1 .

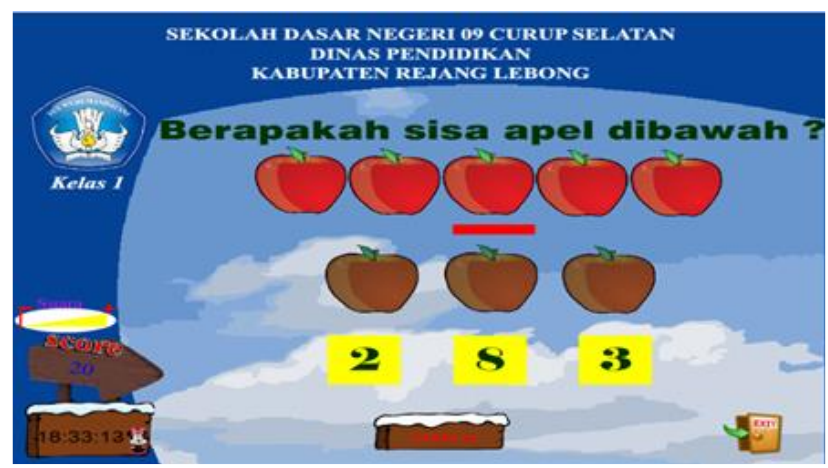

Gambar 9. Tampilan Soal 5 Untuk Kelas 1 Semester 1

c) Sub Menu Soal Kelas 1 Semester 2

Pada sub menu ini terdapat 5 soal matematika kelas 1 semester 2 .

\section{Soal 1}

Berikut tampilan soal pertama dari pilihan sub menu soal kelas 1 semester 2 .

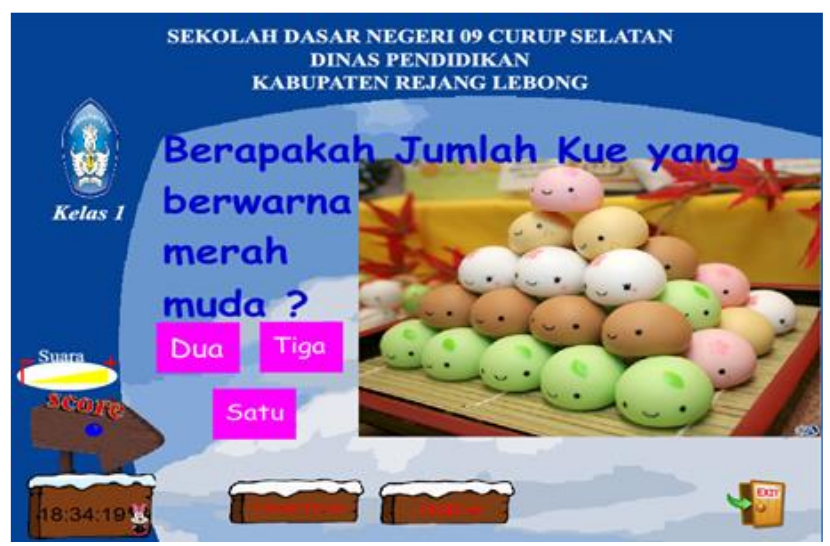

Gambar 10. Tampilan Soal 1 Untuk kelas 1 Semester 2

Soal 2

Berikut tampilan soal kedua dari pilihan sub menu soal kelas 1 semester 2 .

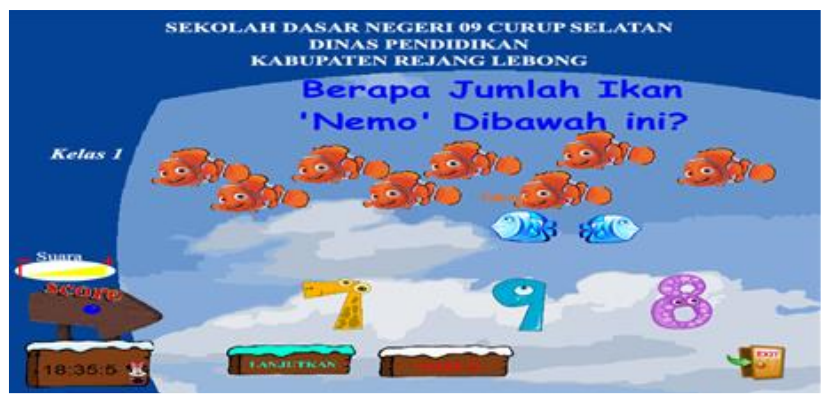

Gambar 11. Tampilan Soal 2Untuk kelas 1 Semester 2

Soal 3

Berikut tampilan soal ketiga dari pilihan sub menu soal kelas 1 semester 2 .

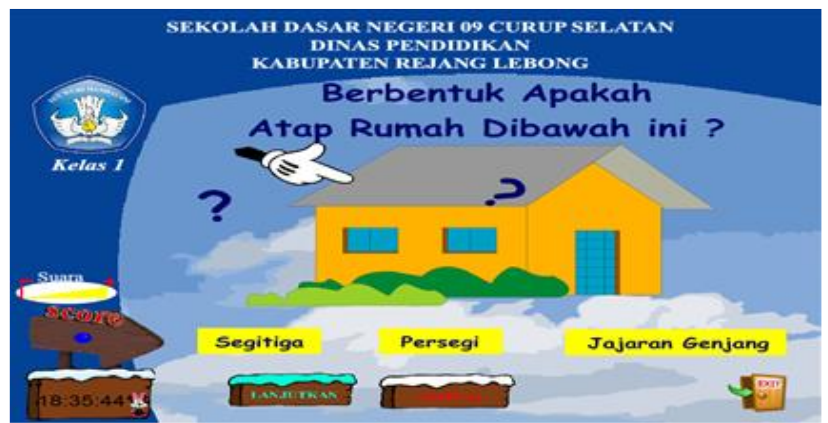

Gambar 12. Tampilan Soal 3 Untuk kelas 1 Semester 2

Soal 4

Berikut tampilan soal keempat dari pilihan sub menu soal kelas 1 semester 2 .

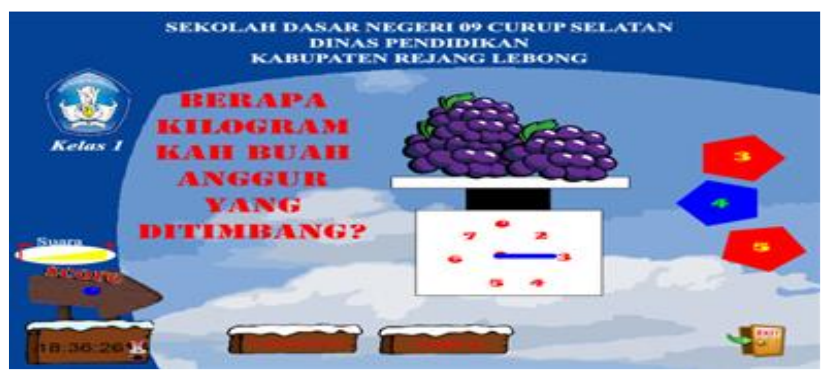

Gambar 13. Tampilan Soal 4 Untuk kelas 1 Semester 2

Quis Interaktif Matematika untuk Anak Sekolah Dasar ... 


\section{Soal 5}

Berikut tampilan soal kelima dari pilihan sub menu soal kelas 1 semester 2 .

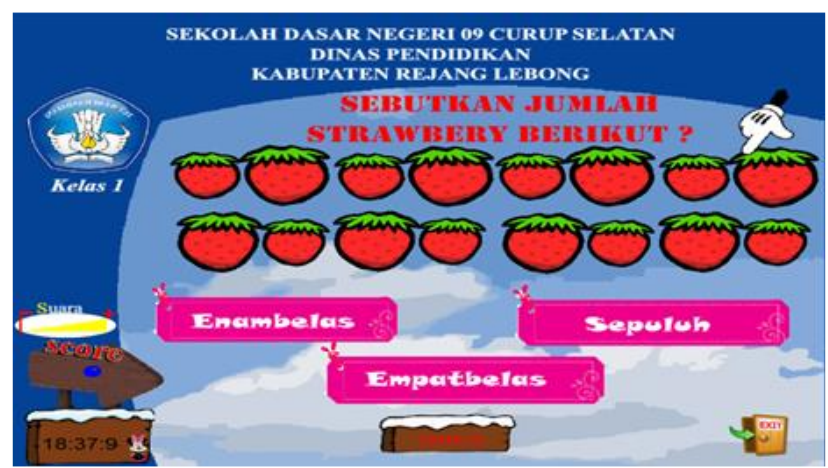

Gambar 14. Tampilan Soal 5 Untuk Kelas 1 Semester 2

\section{4) Menu Kelas 2}

Pada pilihan tombol kelas 2 terdapat sub menu tampilan pilihan semester dan tampilan soal per semester.

\section{a) Sub Menu Semester Kelas 2}

Pada tampilan sub menu semester kelas 2 terdapat 2 pilihan semester. Tampilan menu ini dapat dilihat pada Gambar 15.

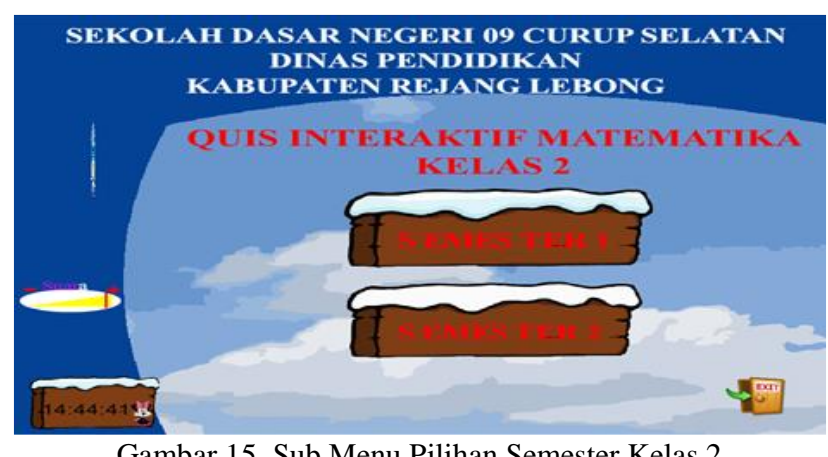

Gambar 15. Sub Menu Pilihan Semester Kelas 2

b) Sub Menu Soal Kelas 2 Semester 1

Pada sub menu ini terdapat 5 soal matematika kelas 2 semester 1 .

\section{Soal 1}

Berikut tampilan soal pertama dari pilihan sub menu soal kelas 2 semester 1.

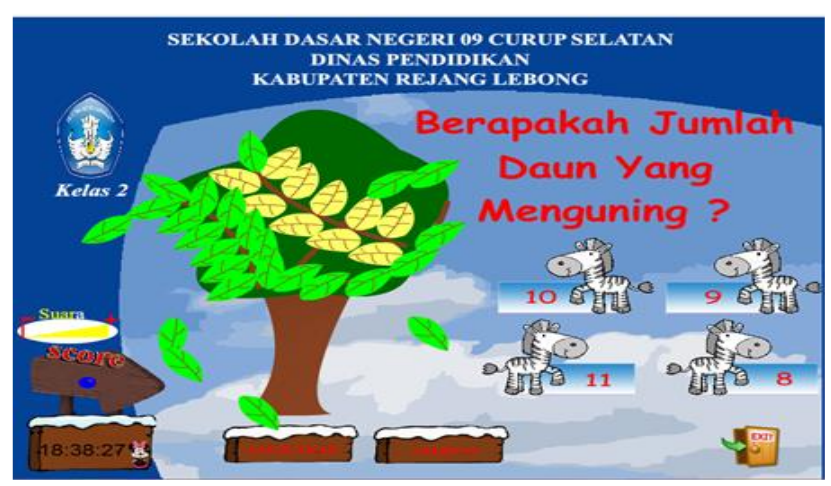

Gambar 16. Tampilan Soal 1 Untuk Kelas 2 Semester 1

\section{Soal 2}

Berikut tampilan soal kedua dari pilihan sub menu soal kelas 2 semester 1 .

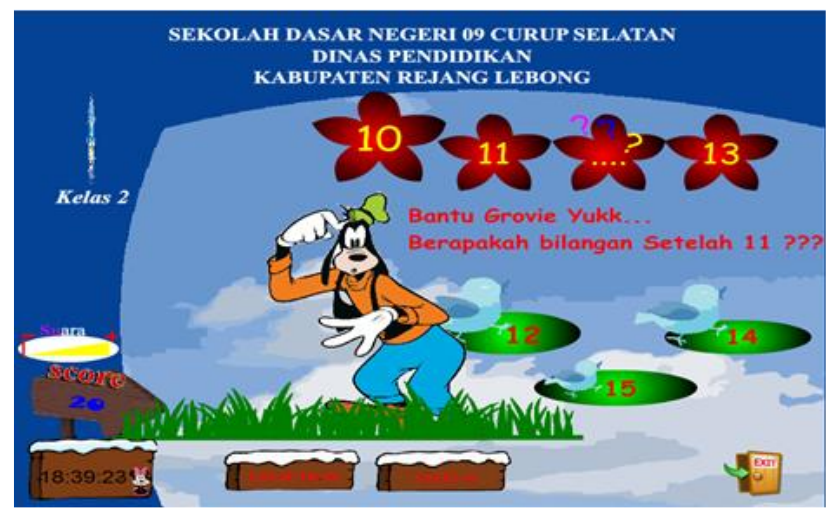

Gambar 17. Tampilan Soal 2Untuk kelas 2 Semester 1

Soal 3

Berikut tampilan soal ketiga dari pilihan sub menu soal kelas 2 semester 1 .

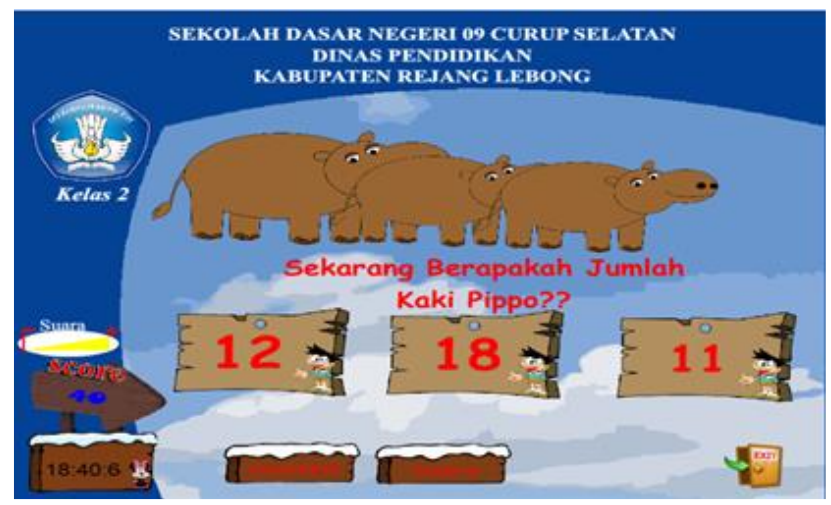

Gambar 18. Tampilan Soal 3Untuk kelas 2 Semester 1

Soal 4

Berikut tampilan soal keempat dari pilihan sub menu soal kelas 2 semester 1 .

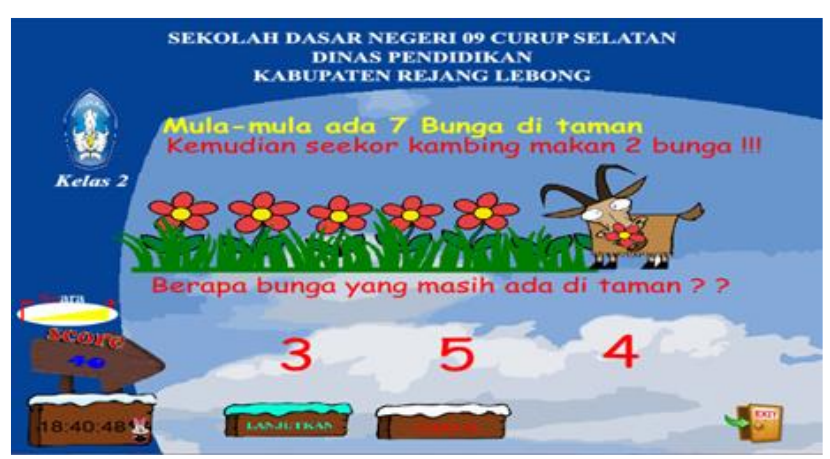

Gambar 19. Tampilan Soal 4 Untuk kelas 2 Semester 1

\section{Soal 5}

Berikut tampilan soal kelima dari pilihan sub menu soal kelas 2 semester 1 . 


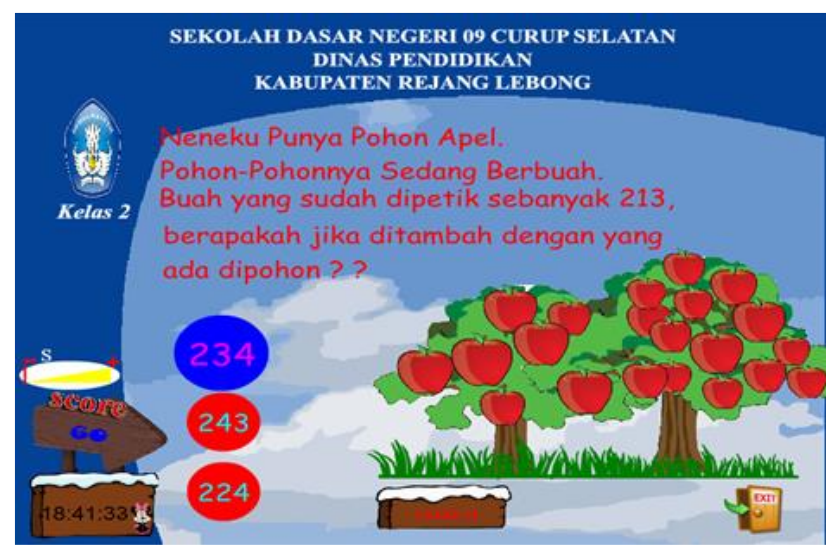

Gambar 20. Tampilan Soal 5 Untuk kelas 2 Semester 1

c) Sub Menu Soal Kelas 2 Semester 2

Pada sub menu ini terdapat 5 soal matematika kelas 2 semester 2 .

\section{Soal 1}

Berikut tampilan soal pertama dari pilihan sub menu soal kelas 2 semester 2 .

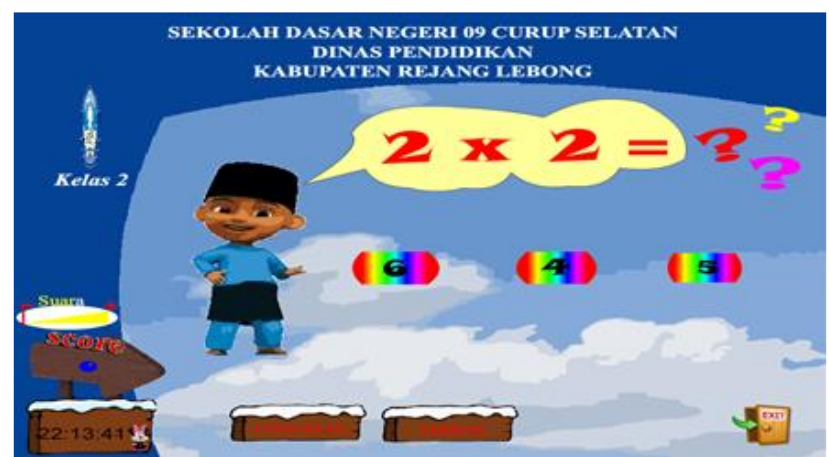

Gambar 21. Tampilan Soal 1Untuk kelas 2 Semester 2

\section{Soal 2}

Berikut tampilan soal kedua dari pilihan sub menu soal kelas 2 semester 2 .

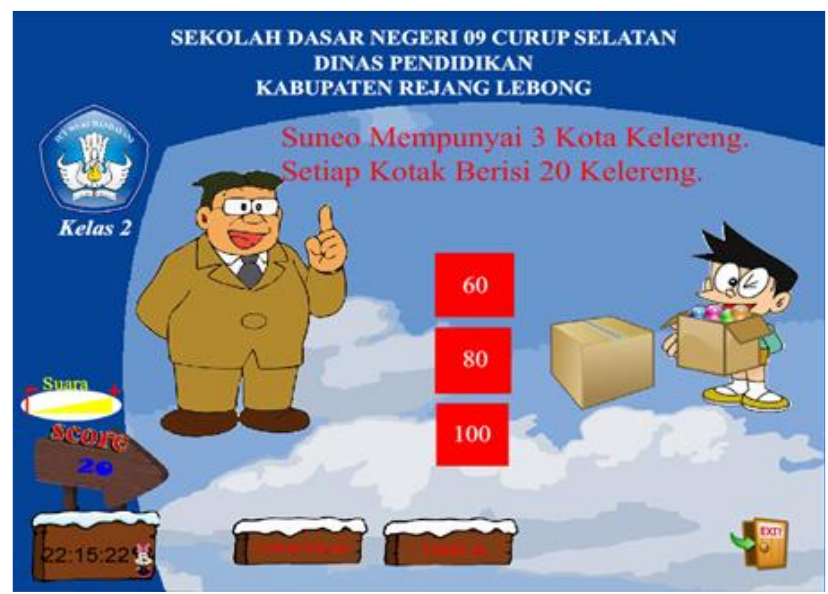

Gambar 22. Tampilan Soal 2Untuk kelas 2 Semester 2

Soal 3

Berikut tampilan soal ketiga dari pilihan sub menu soal kelas 2 semester 2 .

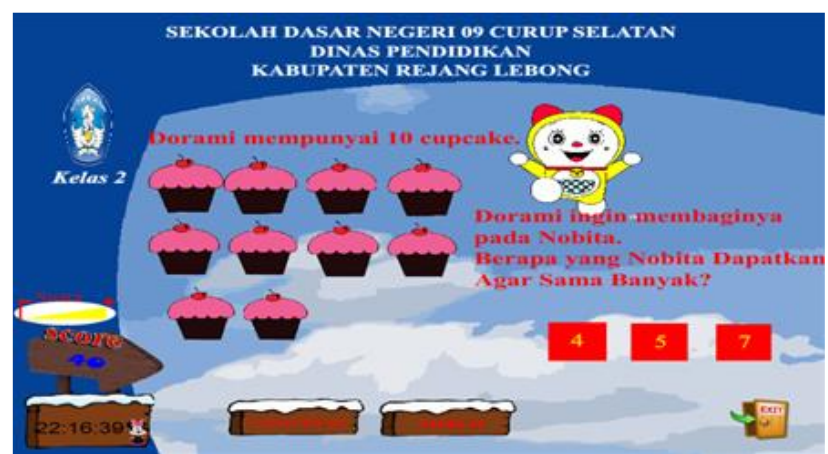

Gambar 23. Tampilan Soal 3Untuk kelas 2 Semester 2

Soal 4

Berikut tampilan soal keempat dari pilihan sub menu soal kelas 2 semester 2 .

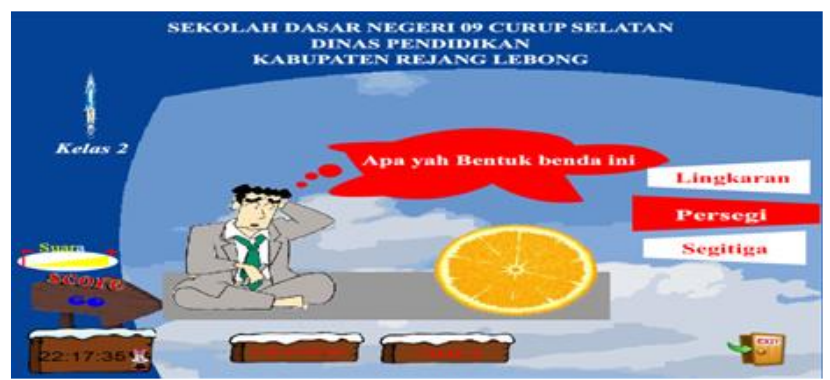

Gambar 24. Tampilan Soal 4Untuk kelas 2 Semester 2

Soal 5

Berikut tampilan soal kelima dari pilihan sub menu soal kelas 2 semester 2 .

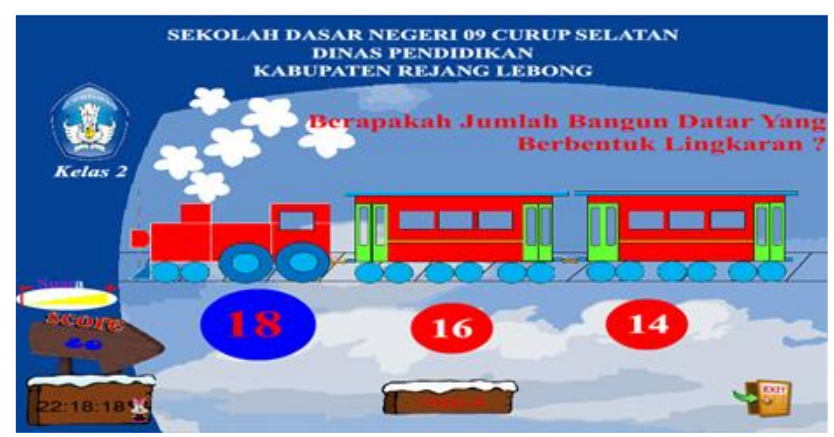

Gambar 25. Tampilan Soal 5 Untuk kelas 2 Semester 2

Untuk kelas yang selanjutnya ditemui menui yang sama sehingga untuk tampilan menu kelas berikunya akan memiliki bentuk yang sama dengan menu kelas sebelumnya.

\section{5) Menu Penilaian}

Berikut tampilan hasil penilaian dari soal-soal yang telah dijawab sesuai dengan kelas dan semester masing masing, terdapat juga predikat nilai yang didapat dari hasil penilaian dan tombol coba lagi untuk mengulang ke soal pertama jika belum puas dengan hasil yang didapat dan tombol keluar untuk kembali ke halaman sebelumnya, bentuk tampilan dapat dilihat pada gambar 26. 


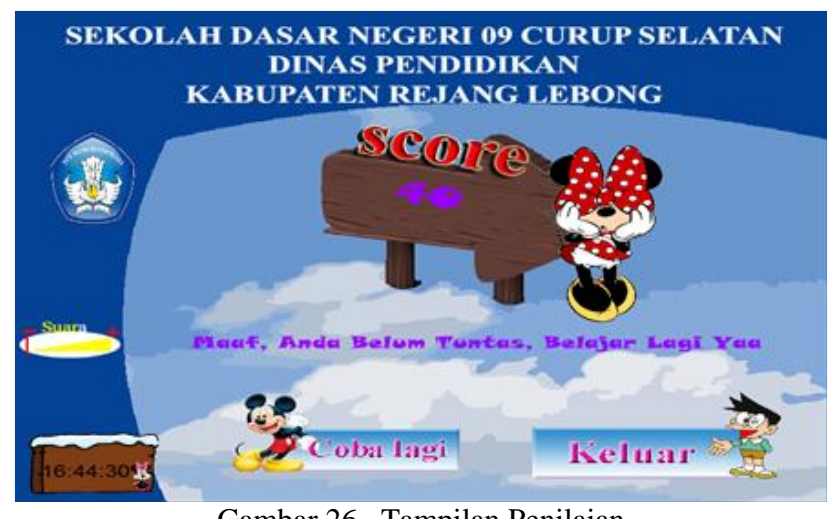

Gambar 26. Tampilan Penilaian

\section{B) Hasil Pengujian}

Quis interaktif ini menggunakan Adobe Flash CS 5.5 dengan actionscript 2.0 sebagai bahasa pemprograman sehingga apabila terjadi kesalahan pada script maka aplikasi quis interaktif tidak dapat berjalan dengan sempurna, quis interaktif dibuat dalam bentuk file dengan ekstensi (.exe) agar bisa langsung dijalankan tanpa harus menginstal program Adobe Flash CS 5.5 .

Dan dilakukan pengujian quis interaktif dijalankan untuk anak sekolah dasar yang langsung dimainkan oleh anak sekolah dasar dengan bimbingan guru dan orang tua. Berdasarkan hasil pengujian yang dilaksanakan tidak terdapat kesalahan dan diteliti dengan benar. Sampel dari anak sekolah dasar untuk penilaian uji coba aplikasi quis interaktif matematika ini dilakukan terhadap 6 anak usia sekolah dasar. Dari hasil kuisioner tersebut diperoleh data sebagai berikut sesuai masing-masing pertanyaan.

Tabel 1. Hasil Kuisioner Uji Coba Aplikasi

\begin{tabular}{|c|c|c|c|c|}
\hline \multicolumn{2}{|r|}{ PERTANYAAN } & SM & M & TM \\
\hline 1) & $\begin{array}{l}\text { Apakah tampilan quis } \\
\text { interaktif menarik? }\end{array}$ & 6 & 0 & 0 \\
\hline 2) & $\begin{array}{l}\text { Apakah Tulisan Soal Pada } \\
\text { Quis Mudah Dibaca? }\end{array}$ & 4 & 2 & 0 \\
\hline 3) & $\begin{array}{l}\text { Apakah Quis Mudah } \\
\text { Dimainkan? }\end{array}$ & 5 & 1 & 0 \\
\hline 4) & $\begin{array}{l}\text { Apakah Maksud Soal Pada } \\
\text { Quis Mudah Dimengerti? }\end{array}$ & 4 & 2 & 0 \\
\hline 5) & $\begin{array}{l}\text { Apakah Quis Membantu } \\
\text { Dalam Pelajaran } \\
\text { Matematika? }\end{array}$ & 4 & 2 & 0 \\
\hline 6) & $\begin{array}{l}\text { Apakah Quis Dapat } \\
\text { Meningkatkan Minat } \\
\text { Belajar Matematika? }\end{array}$ & 5 & 1 & 0 \\
\hline & JUMLAH & 28 & 8 & 0 \\
\hline & PERSENTASE (\%) & 77,77 & 22,22 & 0 \\
\hline
\end{tabular}

Dari tabel diatas dapat terlihat bahwa pada masing-masing pertanyaan memiliki nilai sendiri. Untuk lebih jelasnya akan penulis uraikan sebagai berikut:
1) Pertanyaan 1 (Apakah tampilan quis interaktif menarik ?)

Berdasarkan tabel diatas dari 6 anak usia sekolah dasar sebagai responden, 6 anak menjawab Sangat Menarik yang artinya tampilan quis interaktif menarik minat anak usia sekolah dasar.

2) Pertanyaan 2 (Apakah Tulisan Soal Pada Quis Mudah Dibaca ?)

Berdasarkan tabel diatas dari 6 anak usia sekolah dasar sebagai responden, 4 anak menjawab Sangat Mudah, 2 anak menjawab Mudah, dan 0 anak menjawab Tidak Mudah, yang artinya tulisan soal pada quis mudah dibaca anak usia sekolah dasar.

3) Pertanyaan 3 (Apakah Quis Mudah Dimainkan ?) Berdasarkan tabel diatas dari 6 anak usia sekolah dasar sebagai responden, 5 anak menjawab Sangat Mudah, 1 anak menjawab Mudah, dan 0 anak menjawab Tidak Mudah, yang artinya quis mudah dimainkan anak usia sekolah dasar.

4) Pertanyaan 4 (Apakah Maksud Soal Pada Quis Mudah Dimengerti ?)

Berdasarkan tabel diatas dari 6 anak usia sekolah dasar sebagai responden, 4 anak menjawab Sangat Mudah, 2 anak menjawab Mudah, dan 0 anak menjawab Tidak Mudah, yang artinya maksud dari soal yang dierikan pada quis mudah dimengerti anak usia sekolah dasar.

5) Pertanyaan 5 (Apakah Quis Membantu Dalam Pelajaran Matematika ?)

Berdasarkan tabel diatas dari 6 anak usia sekolah dasar sebagai responden, 4 anak menjawab Sangat Membantu, 2 anak Menjawab Mmbantu, dan 0 anak menjawab Tidak Membantu yang artinya quis membantu dalam pelajaran matematika untuk anak usia sekolah dasar.

6) Pertanyaan 6 (Apakah Quis Dapat Meningkatkan Minat Belajar Matematika ?)

Berdasarkan tabel diatas dari 6 anak usia sekolah dasar sebagai responden, 5 anak menjawab Sangat Meningkatkan, 1 anak menjawab Meningkatkan, dan 0 anak menjawab Tidak Meningkatkan, yang artinya quis dapat meningkatkan minat belajar matematika anak usia sekolah dasar.

\section{PENUTUP}

\section{A) Kesimpulan}

1) Hasil dari penelitian ini adalah terciptanya quis interaktif matematika untuk anak sekolah dasarnegeri 09 Curup Selatan yang dikembangkan dengan bantuan program Adobe Flash CS 5.5.

2) Setelah diajukan aplikasi ini sesuai digunakan untuk sarana bermain dan belajar 
anak serta pengenalan komputer terhadap anak pada SD Negeri 09 Curup Selatan.

3) Program aplikasi ini dapat dijalankan/digunakan pada komputer dengan spesifikasi yang berbeda.

4) Sebagai alternatif baru bagi tutor, guru atau orang tua mengajarkan anak matematika sambil bermain untuk lebih meningkatkan pengetahuan anak tentang materi matematika.

\section{B) Saran}

Berdasarkan dari kesimpulan diatas, maka dapat diberikan beberapa saran yang bermanfaat pada SDN 09 Curup Selatan sebagai berikut :

1) Dapat berfungsi efesien sebagai sarana pembelajaran dalam mengajarkan anak melalui komputer dengan bentuk quis interaktif.

2) Dapat berfungsi dengan baik dengan bimbingan guru, tutor maupun orang tua murid.

\section{DAFTAR PUSTAKA}

Arizal, Rosfen. 2007. Matematika Kelas 4 Sekolah Dasar. Yudhistira. Bogor

Armaini, Rina, dkk. 2005. Matematika Untuk Siswa Sekolah Dasar Kelas 3. Acarya Media Utama. Bandung

Departermen Pendidikan Nasional, 2008. Kamus Besar Bahasa Indonesia. Jakarta: PT. Grafindo Pustaka Utama.

Farida Tatik, 2009. Rumus Matematika dan Fisika. Karya Gemilang Utama. Surabaya.

Hilda, dkk. 2010. Buku Kerja Tematik Matematika Jilid 2A Untuk Sekolah Dasar Kelas I Semester 2. Erlangga. Bandung 2010. Buku Kerja Tematik Matematika Jilid 2B Untuk Sekolah Dasar Kelas II Semester 2. Erlangga. Bandung

Indriyastuti. 2009. Dunia Matematika Untuk Kelas V SD dan MI. Platinum. Solo

Maulana, Irman. 2014. Pemrograman Game dengan Actionscript pada Adobe Flas CS 3. Andi Offset. Yogyakarta,

Pratama, Eka. 2014. Komputer dan Masyarakat. Informatika. Bandung.
Purnama, Bambang Eka. Pengembangan Media Pembelajaran Kuis Interaktif. Graha Ilmu. Yogyakarta,

Sudwiyanto, dkk. 2007. Tampil Berhitung Matematika Untuk SD Kelas V. Erlangga. Jakarta

Suhendra, Imang, dkk. 2006. Terampil Matematika Untuk Kelas 6 SD. Yudhistira. Jakarta

Vaughan, T, 2005. Multimedia: Making It Work. Edisi Ke-6. Andi Offset. Yogyakarta

Widada,dkk. 2014. Cara Mudah Membuat Madia Pembelajaran Game Kuis Menggunakan Flash. Gava Media. Yogyakarta.

www.wikipedia.org, 2016. Tentang Sekolah Dasar. 